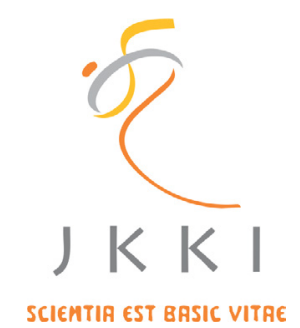

Jurnal Kedokteran dan Kesehatan Indonesia

Indonesian Journal of Medicine and Health

Journal homepage : www.journal.uii.ac.id/index.php/JKKI

\title{
Recurrent Mycobacterium tuberculosis infection in systemic lupus erythematosus patient: case report and review
}

Anthony Paulo Sunjaya*1, Devi Astri Rivera Amelia ${ }^{2}$

${ }^{1}$ Faculty of Medicine, Tarumanagara University, Jakarta, Indonesia

${ }^{2}$ Department of Internal Medicine, Ciawi General Hospital, West Java, Indonesia

Case Report

\begin{tabular}{|c|c|}
\hline & \\
\hline ARTICLE INFO & \multirow{5}{*}{$\begin{array}{l}\text { Systemic Lupus Erythematosus (SLE) is an autoimmune disorder } \\
\text { characterised by an underlying immunodeficiency state, worsened by } \\
\text { the use of immunosuppressive drugs in its treatment. Hence patients } \\
\text { with SLE are at increased risk of opportunistic infections, one of which } \\
\text { is tuberculosis. Tuberculosis (TB) is one of the most common infectious } \\
\text { diseases globally, with Indonesia having the second highest prevalence } \\
\text { in the world. Further research towards better management of these two } \\
\text { disease entities is thus required. We report a patient with SLE flare and } \\
\text { recurrent tuberculosis infection. }\end{array}$} \\
\hline $\begin{array}{l}\text { words: } \\
\text { cemic lupus erythematosus, } \\
\text { urrent tuberculosis, } \\
\text { oimmune haemolytic ane- }\end{array}$ & \\
\hline & \\
\hline$\overline{\text { DOI : } 10.20885 / \text { JKKI.Vol10.Iss1.art14 }}$ & \\
\hline & \\
\hline & \multirow{2}{*}{$\begin{array}{l}\text { Lupus eritematosus sistemik (SLE) merupakan kelainan autoimun yang } \\
\text { ditandai dengan kondisi imunodefisiensi, yang diperburuk kondisinya } \\
\text { selama pengobatan dengan penggunaan obatimunosupresif. Pasien dengan } \\
\text { SLE memiliki risiko infeksi oportunistik, salah satunya adalah tuberkulosis. } \\
\text { Tuberkulosis (TB) adalah salah satu penyakit menularyang paling umum di } \\
\text { dunia. Indonesia memiliki prevalensi tertinggi kedua di dunia. Oleh karena } \\
\text { itu diperlukan penelitian lebih lanjut mengenai manajemen yang lebih baik } \\
\text { dari penyakit ini. Kami melaporkan seorang pasien dengan ruam SLE dan } \\
\text { infeksi tuberkulosis berulang. }\end{array}$} \\
\hline $\begin{array}{l}\text { Copyright @2019 Authors. } \\
\text { This is an open access article } \\
\text { distributed under the terms } \\
\text { of the Creative Commons At- } \\
\text { tribution-NonCommercial 4.0 } \\
\text { International Licence (http:// } \\
\text { creativecommons.org/licences/ } \\
\text { by-nc/4.0/). }\end{array}$ & \\
\hline
\end{tabular}

\section{INTRODUCTION}

Systemic Lupus Erythematosus (SLE) is an autoimmune disorder characterised by an underlying immunodeficiency state worsened by the use of immunosuppressive drugs in its treatment. Hence patients with SLE are at increased risk of opportunistic infections, one of which is tuberculosis. Tuberculosis (TB) is one of the most common infectious diseases globally, with Indonesia having the second highest prevalence in the world today. A previous study in Spain has reported a six fold increase in TB incidence in the SLE group compared to the general population. In Hongkong, a similar study has reported an increased risk of up to
15 fold in SLE patients. We report a case of SLE flare with recurrent tuberculosis infection and autoimmune haemolytic anaemia. Informed consent was obtained from the patient for this report. $^{1-5}$

\section{CASE PRESENTATION}

A 42-year old female presented to the outpatient department with a one-week history of haemoptysis and discoid skin rash as well as swollen joints over the lower extremities which appeared after her daily methylprednisolone dose was tapered down a week ago. The patient also complained lethargy, night sweats, weight loss (3 kg over two weeks), loss of appetite, 
nausea, epigastric pain, photosensitivity and arthralgia throughout all the joints in her body. Also, she suffered from diarrhoea two days before being admitted. A history of fever, chest pain, urinary difficulties, history of trauma or prior bleeding was denied by the patient. The rashes, photosensitivity and arthralgia started to occur when she was exposed to bright sunlight a week ago and after hearing of her mother getting ill.

The patient had a history of systemic lupus erythematosus first diagnosed two years ago (confirmed by antinuclear antibodies/ ANA and Anti-double stranded DNA /Anti-dsDNA profile test) and had two previous episodes of tuberculosis infection which had been completely treated and declared cured based on results from ChestX-Ray and bacteriologic examination. She is currently in her ten-month course of fixed dosed combination anti-TB drug (FDC) for her third episode of TB infection which diagnosis has been confirmed by both Chest X-Ray and bacteriologic examination.

\section{Clinical findings}

Examination of the patient demonstrated a conjunctival pallor, coarse crackles over the apex of the left thorax, rhonchi throughout the left thorax, swollen joints and discoid rash over both lower extremity. All other physical examinations were within normal limits (Figure 1).

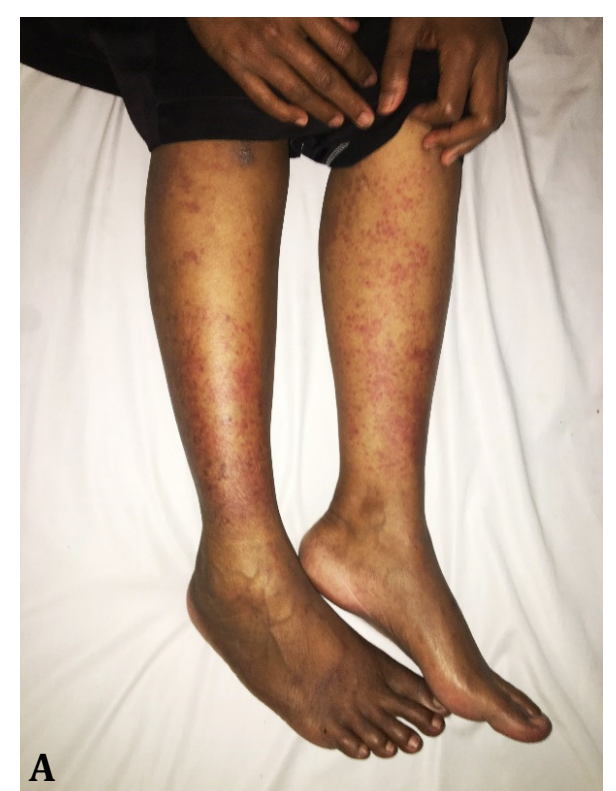

Figure 1.Discoid lesions on the extremities

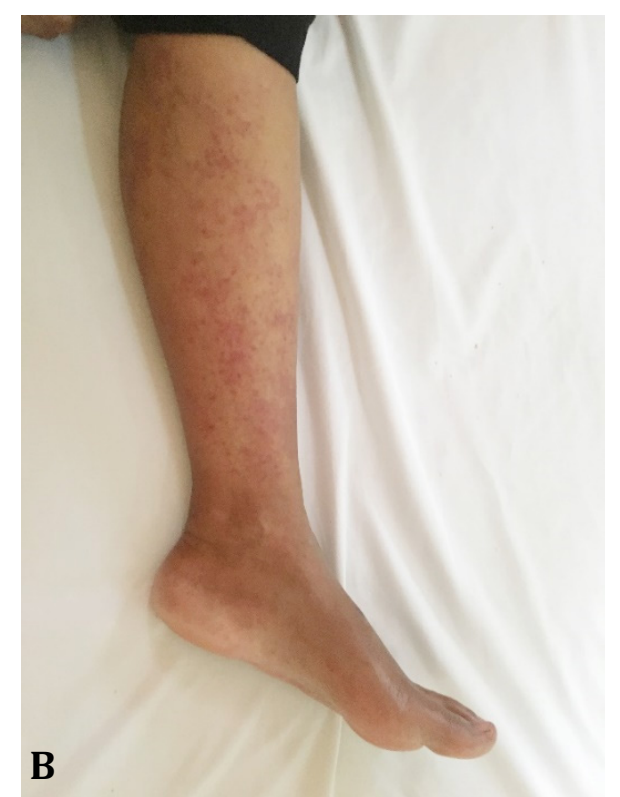

(A: Pre-therapy and B: Post-therapy).

previous chest X-rays of the patient taken at 3, 6 and 8 months have reported bilateral pulmonary infiltrates without any pulmonary cavities. No pulmonary cavity have been found (Figure 2).

The patient was diagnosed with SLE Flare, haemoptysis et causa Tuberculosis on therapy, Autoimmune Hemolytic Anemia and Gastroenteritis. She was treated with FDC, and acetylcysteine ( $3 \times 1$ tablet), methylprednisolone (1 x $125 \mathrm{mg}$ ), transfusion of packed red cells (500 ml), thrombocyte was performed, and anti- 


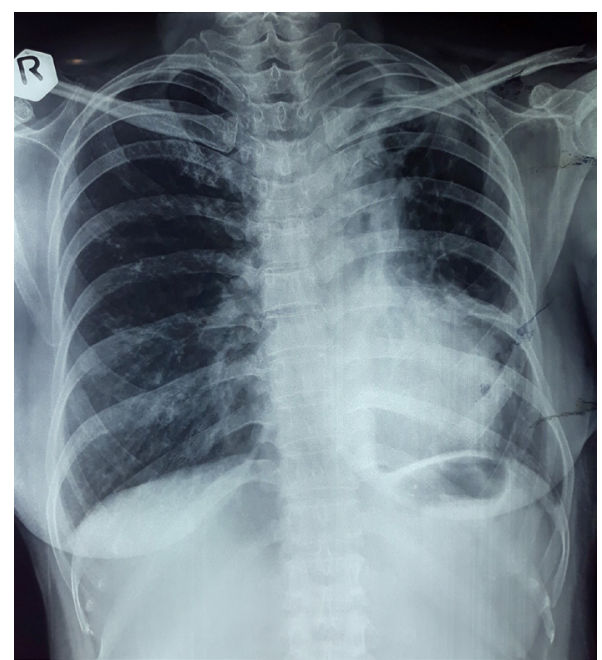

Figure 2. Posteroanterior chest X-Ray of the patient at admission

Table 1. Laboratory and Peripheral Blood Smear Results

\begin{tabular}{lcc}
\hline \multicolumn{1}{c}{ Variable } & Result & Normal Values \\
\hline Hemoglobin (g/dL) & 9.6 & $11.7-15.5$ \\
MCV (fL) & $80 \mathrm{fL}$ & $80-96$ \\
MCH (pg) & $28 \mathrm{pg}$ & $27-33$ \\
MCHC (g/dL) & $35 \mathrm{~g} / \mathrm{dL}$ & $33-36$ \\
Hematocrit (\%) & 29.0 & $35-47$ \\
Leucocyte (000s/uL) & 3.3 & $4-11$ \\
Basophil & 0 & $0-1$ \\
Eosinophil & 6 & $1-3$ \\
Banded Neutrophil & 0 & $2-6$ \\
Segmented Neutrophil & 66 & $50-70$ \\
Lymphocyte & 22 & $20-40$ \\
Monocyte & 6 & $2-8$ \\
Thrombocyte (000s/ul) & 18 & $150-440$ \\
Random Blood Glucose (mg/dL) & 130 & $80-120$ \\
Ureum (mg/dL) & 38.7 & $10-50$ \\
Creatinine (mg/dL) & 1.00 & $0.60-1.30$ \\
Uric Acid (mg/dL) & 7.4 & $2.6-6.7$ \\
SGOT & 29 & $0-35$ \\
SGPT & 13 & $0-35$ \\
Natrium (mEq) & 125 & $135-145$ \\
Potassium (mEq) & 3.5 & $3.5-5.5$ \\
Chloride (mEq) & 95 & $95-106$ \\
Direct Coombs Test & $(+)$ & $(-)$ \\
\hline
\end{tabular}




\begin{tabular}{ll}
\hline & Peripheral Blood Morphology \\
\hline Erythrocyte & Hypochromic Normocytic; Normoblast (-) \\
& Ovalocyte (+), Elliptocyte (+), Teardrop cell $(+)$ \\
Leucocyte & Morphology within normal limits; Blast $(-)$ \\
& Lower Cell Count \\
& Rise in Eosinophils \\
Thrombocyte & Morphology within normal limits \\
& Low cell count and distribution \\
Conclusion & Hypochromic normocytic Anemia with Eosinophillia and \\
& Thrombocytopenia \\
\hline
\end{tabular}

emetics (Ondansetron $2 \times 8 \mathrm{mg}$ ). Throughout her stay, no further haemoptysis was reported by the patient, and her discoid lesions subsequently fade, subside and reduce in number. The patient was discharged upon resolution of symptoms with oral FDC and methylprednisolone (3 x 16 $\mathrm{mg}$ ).

A week post discharge, the patient was reevaluated in the outpatient department with her SLE under remission, and no further haemoptysis was reported. Her TB drug regiment was hence continued. Whereas, her methylprednisolone was once again tapered down to $2 \times 16 \mathrm{mg}$ with the addition of chloroquine 2 x $150 \mathrm{mg}$ daily.

\section{DISCUSSION}

Earlier diagnosis, better monitoring and increased use of immunosuppressant have to lead to much-improved survival rates among SLE patients today compared to decades ago. However, increased life expectancy and usage of immunosuppressive therapy has brought forward other challenges in managing SLE patients including drug-related adverse effects such as recurrent infections and long term SLE sequelae such as accelerated atherosclerosis. Infection is now the leading cause of death followed by atherosclerosis among SLE patients. ${ }^{6,7}$

Tuberculosis is an opportunistic infection often found in patients with immunosuppression either as a result of their disease or due to immunosuppressive therapy. Several previous studies have shown an increased risk of TB among SLE patients, especially in those living in endemic areas. Studies have also reported extrapulmonary TB (EPTB) as more prevalent in SLE patients compared to pulmonary TB. In a previous study in China, among 452 patients with SLE, $73.8 \%$ had EPTB while only $23.8 \%$ had pulmonary TB. In another larger scale study of 3000 SLE patients, $52.4 \%$ had EPTB while $47.6 \%$ had pulmonary TB. Similar findings were also reported in a cohort of patients in Romania. When these patients were infected with TB, they were also reported to be more susceptible to the risk of dissemination with previous studies reporting up to $50 \%$ of patients with TB and SLE presenting with a concurrent disseminated TB infection. ${ }^{8-12}$

The diagnosis of TB in SLE patient especially that of EPTB is clinically challenging due to the lack of specific symptoms to guide diagnosis. These patients often present with a constellation of prodromal symptoms namely unexplained fever, joint pain, fatigue and serositis which are also showing symptoms in patients with SLE. In a cohort study of SLE patients with TB, fever was found to be the most crucial red-flag for the diagnosis of TB (OR 73.1; 95\% CI 15.2-352.7; $\mathrm{p}<0.001$ ), with other frequent manifestations being weight loss and cough. ${ }^{11}$

Due to the above clinical diagnosis challenges, previous studies have shown that the time interval between TB onset to diagnosis in SLE patients varies from 1 month up to 1 year. Definite diagnosis would require a high degree of clinical suspicion from the physician and is determined based on analysis of body fluids and tissues. ${ }^{4,13}$ In diagnosing patients with latent TB infection, the 
American Thoracic Society, Infectious Diseases Society of America and Centers for Disease Control (CDC) joint guidelines on diagnosis of tuberculosis recommends the use of interferon- $\gamma$ release assay (IGRA) rather than a tuberculin skin test (TST) in patients older than 5 years, although TST is an acceptable alternative in situations where IGRA is unavailable or too costly. A TST reaction of $5 \mathrm{~mm}$ or higher is considered positive in patients currently undergoing immunosuppressive therapy and $10 \mathrm{~mm}$ or greater in patients living in endemic areas. A reaction of $15 \mathrm{~mm}$ or greater is positive for all patients. Patients with SLE who are at increased risk of TB infection are also recommended to undergo annual TST examination. ${ }^{14}$

Haematological manifestations of SLE have been reported in $10-83 \%$ of adultonset SLE patients. However, autoimmune haemolytic anaemia (AIHA) was reported to be uncommonly found, in only $4-10 \%$ of SLE patients. Anti-dsDNA was reported to be the most frequent specific predictor for AIHA in SLE patients. Similar to SLE patients, glucocorticoids and immunosuppressive therapy remain the mainstay of therapy. ${ }^{15}$

Previous studies have also shown that patients with SLE are at increased risk of hyperuricemia similar to this patient. Several mechanisms including inflammation, hypertension and renal involvement are hypothesised to be possible provoking factors of hyperuricemia in SLE patients, which in return further aggravates inflammation, hypertension and renal disease in these patients thus creating a vicious cycle. ${ }^{16}$

A previous study from India reported a reduction in the incidence of active TB in lupus patients following the prescription of isoniazid ( $5 \mathrm{mg} / \mathrm{kg} /$ day; maximum $300 \mathrm{mg} /$ day) together with pyridoxine $10 \mathrm{mg} /$ day for one year in patients with SLE receiving corticosteroid therapy. Even so, the risk and benefits of long term prescription of prophylactic INH in SLE patients must be taken into account on a case by case basis primarily due to the hepatotoxic effects of INH and possible drug-induced lupus secondary to anti-tubercular therapy, which can develop in approximately $20 \%$ of patients receiving isoniazid. ${ }^{17,18}$

\section{Management of SLE Patients with Latent and Active TB Infection Latent TB Infection}

In patients with latent $\mathrm{TB}$ infection, general recommendations suggest treatment with Isoniazid for nine months when TST or IGRA test is positive. ${ }^{17,18}$ In patients with active TB infection, The treatment of patients with TB on SLE do not differ from those without SLE. ${ }^{1,8}$ In a study by Gherghe et al. (2015) from Romania, the use of high dose glucocorticoids and cyclophosphamide was significantly associated with TB with OR 9.6 (CI 1.2-77.5; $\mathrm{p}=0.03$ ) for hd-GC and OR 3.3 (CI 1.2-9.1; $\mathrm{p}=0.02$ ) for cyclophosphamide. Compared with other risk factors such as age, disease duration and socioeconomic status, the use of high dose glucocorticoids was found to be the most critical risk factor for TB infection in SLE patients. ${ }^{11}$

The use of immunosuppressive therapy in patients with SLE has long been reported to be associated with a wide variety of infections. Use of glucocorticoids has been associated with an increased incidence of respiratory and genitourinary tract infections caused by Gramnegative microorganisms as well as infections caused by mycobacterial, cryptococci, listeria, and nocardia. In a retrospective study of 2.717 SLE patients comparing the use of glucocorticoids with other non-glucocorticoid agents, patients with a mean daily dose of more than $7.5 \mathrm{mg} /$ prednisone were reported to be more susceptible to the development of pneumonia, herpes zoster and fungal infectionand fungal infection. Other authors have also reported the same cut off with genitourinary tract infections. ${ }^{19-22}$

Methotrexate, azathioprine, cyclophosphamide and mycophenolate mofetil are other corticoidsparing drugs which make up the current therapeutic armamentarium for SLE. While remaining controversial, the use of isolated cyclophosphamide therapy has been reported by some authors to not significantly increase the risk of infections, except when its use is combined 
with glucocorticoids. Even so, other studies have shown that the use of cyclophosphamide is associated with urinary tract infections, with haemorrhagic cystitis being one of the known complications of cyclophosphamide use. ${ }^{23-26}$ Whereas, mycophenolate mofetil use has also been associated with cystitis, upper airway infection, bronchitis and cellulitis. The use of cyclophosphamide, prednisone and azathioprine has also been associated with herpes zoster infections. ${ }^{23,27,28}$

In contrast, a previous study by RuizIrastorza et al. on the risks of infection among SLE patients has reported a 16 -fold reduction in risk of major infection in patients prescribed with antimalarials namely hydroxychloroquine and chloroquine. This was supported by other studies by Siso et al. (2008) and Bulthink. The most recent British Society of Rheumatology Guidelines (2018) recommended dose for hydroxychloroquine use is $200-400 \mathrm{mg} /$ day per oral and chloroquine $125-250 \mathrm{mg}$ per oral in single or divided doses. ${ }^{20,29-31}$

Anti-malarials reduce the risk of infection through its various antimicrobial and immunomodulatory effects. In addition to its anti-parasitic effect against malaria, in vitro studies have shown antimicrobial properties against bacteria (Borrelia burgdorferi, E. coli, Francisella tularensis, Legionella pneumophila, Tropheryma whipplei, S. aureus, Mycobacterium spp., Salmonella typhi), fungi (Aspergillus fumigatus, Cryptococcus neoformans, Histoplasma capsulatum) and viruses including the human immunodeficiency virus. ${ }^{32}$ These antibacterial effects are hypothesised to be mediated by $\mathrm{pH}$-dependent iron deprivation and increase phagolysosomal $\mathrm{pH}$ which inhibits the growth of intracellular organisms. Increase in lysosomal $\mathrm{pH}$ has also been linked to its antiviral effects. ${ }^{33}$

While the timely administration and dosing of immunosuppressive are essential in SLE patients to achieve optimal control, minimising flareup of disease and long term damage, cautious surveillance and dose titration are equally essential to avoid recurrent infections such as TB and other associated comorbidities which have been proven to be just as fatal. In a single study in India, prescription of isoniazid (5 mg/ $\mathrm{kg} /$ day; maximum $300 \mathrm{mg} /$ day) together with pyridoxine $10 \mathrm{mg} /$ day for one year in patients with SLE receiving corticosteroid therapy has been demonstrated to lower incidence of active TB infection. Even so, the risk and benefits of long-term prescription of prophylactic INH in SLE patients must be taken into account.

The use of corticoid sparing drugs must always be considered in patients currently dosed with high dose glucocorticoids especially with concurrent infection as they were found to confer a lower risk of infection compared to glucocorticoids in previous studies. The use of anti-malarial agents (hydrochloroquine and chloroquine) have been reported to be beneficial in reducing the risk of infections among SLE patients. However, the risk of irreversible retinopathy must also be considered before prescribing long term antimalarials. Further comprehensive studies comparing the dosing and type of drug prescribed for SLE patients with infection as well as for the prevention of infection remains vital.

\section{CONCLUSION}

SLE patients are at risk of recurrent tuberculosis and other opportunistic infections due to their inherent immunodeficiency state and even more so due to the use of immunosuppressive drugs in their treatment. Annual TB screening is recommended in SLE patients with immunosuppressive therapy as they have increased the propensity of TB infection especially in endemic areas. In these patients with recurrent TB infection, Gene Xpert test for multi-drug resistant tuberculosis is also recommended. Further research towards better management of these two disease entities is required.

\section{CONFLICT OF INTEREST}

All authors declare no conflict of interest with regards to the publication of this manuscript. This publication is self-funded. 


\section{Ethical Approval}

Written informed consent was obtained from the patient before the publication of this case report and accompanying images. A copy of the written inform consent form is available for review upon reasonable request.

\section{Acknowledgement}

None declare.

\section{REFERENCES}

1. Bhattacharya PK, Jamil M, Roy A, Talukdar KK. SLE and tuberculosis: a case series and review of literature. Journal Of Clinical And Diagnostic Research. 2017; 11(2):OR01OR03.

2. Hussein DA, Habeeb RA, El-Azizi NO, et al. Mycobacterium tuberculosis infection in systemic lupus erythematosus patients. Egyptian Rheumatologist. 2017; 39(4):227231.

3. World Health Organization. Global tuberculosis report. World Health Organization; 2017.

4. Erdozain JG, Ruiz-Irastorza G, Egurbide MV, Martinez Berriotxoa A, Aguirre C. High risk of tuberculosis in systemic lupus erythematosus? Lupus. 2006; 15(4):232-5.

5. Mok MY, Lo Y, Chan TM, Wong WS, Lau CS. Tuberculosis in systemic lupus erythematosus in an endemic area and the role of isoniazid prophylaxis during corticosteroid therapy. Journal of Rheumatology. 2005; 32(4):609-15.

6. Ravelli A, Ruperto N, Martini A. Outcome in juvenile onset systemic lupus erythematosus. Current Opinion Rheumatology. 2005; 17(5):568-73.

7. Lee P, Lee T, Ho M, Wong W, Lau YL. Recurrent major infections in juvenile-onset systemic lupus erythematosus-a close link with long-term disease damage. Rheumatology. 2007 August; 46(8):1290-6.

8. Prabu VN, Agrawal S. Systemic lupus erythematosus and tuberculosis: A review of complex interactions of complicated diseases. Journal of Postgraduate Medicine. 2010; 56(3):244-50.
9. Hou CL, Tsai YC, Chen LC, Huang JL. Tuberculosis infection in patients with systemic lupus erythematosus: Pulmonary and extra-pulmonary infection compared. Clinical Rheumatology. 2008; 27(5):557-63.

10. Zhang L, Wang DX, Ma L. A clinical study of tuberculosis infection in systemic lupus erythematosus. Zhonghua Nei Ke Za Zhi. 2008; 47(10):808-10.

11. Gherghe AM, Matei A, Gyorfi H, Soare A, Dobrota R, Sasu M, et al. Increased incidence of tuberculosis among systemic lupus erythematous patients - should tuberculosis screening at diagnosis be the next step? Arthritis Rheumatology. 2015; 67(Suppl 10).

12. Ribeiro F, Szyper-Kravitz M, Klumb EM, Lannes G, Ribeiro FR, Albuquerque EM, et al. Can lupus flares be associated with tuberculosis infection? Clinical Reviews in Allergy \& Immunology. 2010; 38(2-3):163-8.

13. Sayarlioglu M, Inanc M, Kamali S, Cefle A, Karaman O, Gul A, et al. Tuberculosis in turkish patients with systemic lupus erythematosus: Increased frequency of extrapulmonary localization. Lupus. 2004; 13(4):274-8.

14. Lewinsohn DM, Leonard MK, LoBue PA, Cohn DL, Daley CL, Desmong E, et al. Official american thoracic society/infectious diseases society of america/centers for disease control and prevention clinical practice guidelines: diagnosis of tuberculosis in adults and children. Clinical Infectious Disease. 2017 January; 64(2):111-115.

15. Aleem A, Al Arfaj AS, Khalil N, Alarfaj H. Haematological abnormalities in systemic lupus erythematosus. Acta Reumatologica Portuguesa. 2014; 39(3):236-41.

16. Sheikh M, Movassaghi S, Khaledi M, Moghaddassi M. Hyperuricemia in systemic lupus erythematosus: is it associated with the neuropsychiatric manifestations of the disease? Revista Brasileira de Reumatologia. 2016 Nov-Dec; 56(6):471-477.

17. Gaitonde S, Pathan E, Sule A, Mittal G, Joshi VR. Efficacy of isoniazid prophylaxis in patients with systemic lupus erythematosus receiving long term steroid treatment. Annals of Rheumatic Disease. 2002; 
61(3):251-3.

18. Xiao X, Chang C. Diagnosis and classification of drug-induced autoimmunity (DIA). Journal of Autoimmunity. 2014; 48-49:6672.

19. Navarra SV, Leynes MS. Infections in systemic lupus erythematosus. Lupus. 2010; 19(12):1419-24.

20. Ruiz-Irastorza G, Olivares N, Ruiz-Arruza I, Martinez-Berritotxoa A, Egurbide MV, Aguirre C. Predictors of major infections in systemic lupus erythematosus. Arthritis Research and Therapy. 2009; 11(4):R109.

21. Shah M, Chaudhari S, McLaughlin TP, Kan HJ, Bechtel B, Dennis GJ, et al. Cumulative burden of oral corticosteroid adverse effects and the economic implications of corticosteroid use in patients whit systemic lupus erythematosus. Clinical Therapeutics. 2013; 35(4):486-97.

22. Zahr ZA, Fang H, Magder LS, Petri M. Predictors of corticosteroid tapering in sle patients: the hopkins lupus cohort. Lupus. 2013; 22(7):697-701.

23. Skare TL, Dagostini JS, Zanardi PI, Nisihara RM. Infections and systemic lupus erythematosus. Einstein (São Paulo). 2016 JanMar; 14(1):47-51.

24. Danza A, Ruiz-Irastorza G. Infection risk in systemic lupus erythematosus patients: susceptibility factors and preventive strategies. Lupus. 2013; 22(12):1286-94.

25. Koh JH, Lee J, Jung SM, Ju JH, Park SH, Kim HY, et al. Lupus cystitis in korean patients with systemic lupus erythematosus: risk factors and clinical outcomes. Lupus. 2015; 21(12):1300-7.

26. Duran-Barragan S, Ruvalcaba-Naranjo $H$, Rodriguez-Gutierrez L, Solano-Moreno H, Hernandez-Rios G, Sanchez-Ortiz A, et al. Recurrent urinary tract infections and bladder dysfunction in systemic lupus erythematosus. Lupus. 2008; 17(12):1117-21.

27. Pisoni CN, Karim Y, Cuadrado MJ. Mycophenolate mofetil and systemic lupus erythematosus: an overview. Lupus. 2005; 14(Suppl 1).

28. Borba EF, Ribeiro AC, Martin P, Costa LP, Guedes LK, Bonfa E. Incidence, risk factors, and outcome of herpes zoster in systemic lupus erythematosus. Journal of Clinical Rheumatology : practical reports on rheumatic \& musculoskeletal diseases.2010; 16(3):119-22.

29. Siso A, Ramos-Casals M, Bove A, Brito-Zeron P, Soria N, Munoz S, et al. Previous antimalarial therapy in patients diagnosed with lupus nephropathy. Lupus. 2008; 17(4):281-8.

30. Bulthink I, Hamann D, Seelen MA, Hart MH, Dijkmans B, Daha MR, et al. Deficiency of mannose-binding lectin is not associated with infections in patients with systemic lupus erythematosus. Arthritis Research \& Therapy. 2006; 8(6):R183.

31. Gordon C, Amissah-Arthur MB, Gayed M, Brown S, Bruce IN, D'Cruz D, et al. The british society for rheumatology guideline for the management of systemic lupus erythematosus in adults. Rheumatology (Oxford). 2018; 57(1):e1-e45.

32. Rolain JM, Colson P, Raoult D. Recycling of chloroquine and its hydroxyl analogue to face bacterial, fungal and viral infections in the 21st century. Int Journal of Antimicrobial Agents. 2007; 30(4):297-308.

33. Savarino A, Boelaert JR, Cassone A, Majori G, Cauda R. Effects of chloroquine on viral infections: an old drug against today's disease? Lancet Infectious Disease. 2003; 3(11):722(7). 